\title{
Ramipril Increases Adma Concentration in Acute Myocardial Infarction in Rats Induced by Isoproterenol
}

\author{
Gestina Aliska ${ }^{1 * \mathbb{D}}$, Alief Dhuha ${ }^{2}$, Rahmatini Rahmatini1, Rita Hamdani ${ }^{3}$, Nita Afriani ${ }^{4}$, Tofrizal Tofrizal ${ }^{5}$, Hirowati Ali ${ }^{6}$, Nisa \\ Pratiwi $^{7}$, Vinta Nuranisyah ${ }^{7}$, Liganda Endo Mahata ${ }^{1}$, Dedy Kurnia ${ }^{8}$ \\ ${ }^{1}$ Department of Pharmacology and Therapeutics, Faculty of Medicine, Universitas Andalas, West Sumatra, Indonesia; \\ ${ }^{2}$ Department of Anatomy, Faculty of Medicine, Universitas Abdurrab, Pekanbaru, Riau, Indonesia; ${ }^{3}$ Department of Cardiology \\ and Vascular Medicine, Faculty of Medicine, Universitas Andalas, West Sumatra, Indonesia; ${ }^{4}$ Department of Histology, Faculty \\ of Medicine, Universitas Andalas, West Sumatra, Indonesia; ${ }^{5}$ Department of Anatomical Pathology, Faculty of Medicine, \\ Universitas Andalas, West Sumatra, Indonesia; ${ }^{6}$ Department of Biochemistry, Faculty of Medicine, Universitas Andalas, \\ West Sumatra, Indonesia; ${ }^{7}$ Medical Doctor Programme, Faculty of Medicine, Universitas Andalas, West Sumatra, Indonesia; \\ ${ }^{8}$ Department of Anesthesiology and Intensive Therapy, Faculty of Medicine, Universitas Andalas, West Sumatra, Indonesia
}

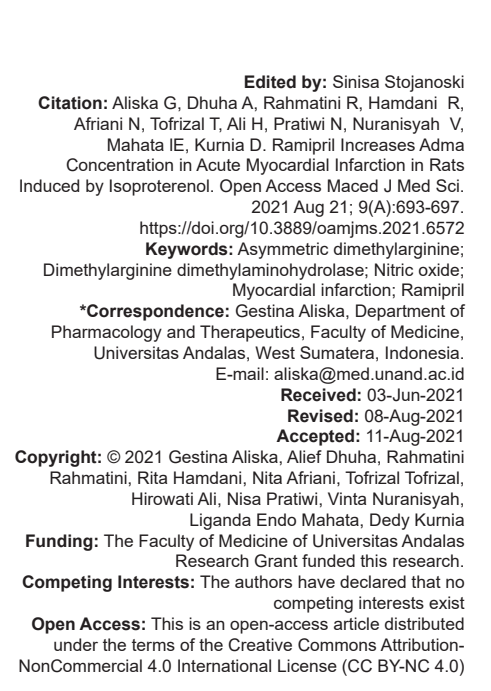

Abstract

BACKGROUND: In experimental animals, the induction of isoproterenol, a synthetic catecholamine, can cause acute myocardial infarction where the pathophysiology and morphology are the same as myocardial infarction in humans. Isoproterenol induction will increase oxidative stress, which will damage the enzyme dimethylarginine dimethylaminohydrolase. Thus, causing asymmetric dimethylarginine (ADMA) levels to increase in circulation. Increased levels of ADMA will inhibit the enzyme nitric oxide (NO) synthase activity, which results in decreased NO resulting in endothelial damage.

AIM: This study aims to determine the effect of Ramipril on ADMA levels in rats (Rattus norvegicus) Wistar strain with acute myocardial infarction.

METHODS: Eighteen male Wistar rats (150-250 g) were randomly allocated into three groups: negative contro group, positive control, and treatment group. The treatment group was pretreated with Ramipril at dose $3 \mathrm{mg} / \mathrm{kg}$ BW orally for 7 days. Acute myocardial infarction was induced in positive control groups and treatment groups by subcutaneous injection of isoproterenol ( $85 \mathrm{mg} / \mathrm{kg} \mathrm{BW}$ ) for 2 consecutive days. $24 \mathrm{~h}$ after the last administration rats from all groups were anesthetized and sacrificed for blood sample collection to evaluate the level of ADMA with Enzyme-linked Immunosorbent Assay method.

RESULTS: The result showed that ADMA levels were increased in the treatment group after pre-treated with Ramipril. CONCLUSION: This study concluded that pretreatment with Ramipril increased ADMA concentration in acute myocardial infarction rats induced by isoproterenol.

\section{Introduction}

Myocardial infarction can be triggered by oxidative stress as a result of chemical reactions from the formation of free radicals that occur in myocardial cells [1]. Increased oxidative stress can cause a decrease in nitric oxide (NO), or in other words, the availability of $\mathrm{NO}$ is reduced. NO is the primary mediator produced from the endothelium and is formed from L-arginine by the enzyme endothelial NO synthase (eNOS) [2], [3]. NO has antiplatelet, anti-inflammatory, vasodilatory properties, and can reduce capillary permeability. A decrease in NO levels can lead to endothelial dysfunction that results in the accumulation of inflammatory cells, vasoconstriction, migration of smooth muscle cells, and increases cytokine formation, which triggers plaque growth [3].
Vascular endothelial dysfunction increases asymmetric dimethylarginine (ADMA) levels [2]. ADMA results from the breakdown of proteins and analogs of endogenous L-arginine, acting as inhibitors of eNOS in endothelial. If an increase in ADMA levels obstructs the work of eNOS, resulting in decreased NO formation [4]. Measurement of ADMA levels can be used as an indicator of NO levels in the blood. The results of this ADMA measurement are negatively correlated with NO levels so that with an increase in ADMA levels, it can be concluded that there has been a decrease in NO synthesis, causing endothelial dysfunction, which can ultimately lead to myocardial infarction [5].

Angiotensin-converting enzyme inhibitors (ACEI) can reduce the mortality rate of patients post-myocardial infarction who are disserted in cardiac dysfunction and are helpful in reducing cardiac remodeling [6]. ACE-I 
inhibits the degradation of bradykinin to increase NO production, which is a potent vasodilator of blood vessels [7]. The increase in NO production occurs due to the eNOS activation, an enzyme for NO formation in endothelial cells. Regarding ADMA, Chen et al. found that ACE-Inhibitor drugs, especially Ramipril, can reduce ADMAlevels through increased enzyme dimethylarginine dimethylaminohydrolase (DDAH), an enzyme for the elimination of ADMA from the blood [8].

\section{Materials and Methods}

\section{Experimental animal and study groups}

This study began after permission was granted by The Research Ethics Committee of the Faculty of Medicine, Universitas Andalas (No. 483/KEP/FK/2019). The study used 18 adolescent (average 12 weeks) Rattus norvegicus male rats weighing from 150-250 g. The animal was kept in standard laboratory condition with stable temperature $\left(25 \pm 2^{\circ} \mathrm{C}\right), 12 \mathrm{~h}$ of light, and $12 \mathrm{~h}$ of darkness, with one rat in each cage fed with rat food and tap water.

The rats were randomly divided into three groups. Group-1: Negative control group $(n=6)$ : only given standard feed without treatment Group-2: Positive control group $(n=6)$ : administration with normal saline for 7 days and induced with isoproterenol dose $85 \mathrm{mg} / \mathrm{kg}$ BW for 2 consecutive days. Group-3: Experimental group $(n=6)$ : pretreated with Ramipril dose $3 \mathrm{mg} / \mathrm{kg} \mathrm{BW}$ for 7 days and induce with isoproterenol dose $85 \mathrm{mg} / \mathrm{kg}$ BW for 2 consecutive days.

\section{Surgical procedure}

A sampling of rat blood was carried out by necropsy technique after rats were anesthetized with ketamine $80 \mathrm{mg} / \mathrm{kg} \mathrm{BW}$ administered intraperitoneally. After the rats were unconscious, the rat was placed supine on the table, and each leg was fixed with tape. The skin incision starts from the xiphoid process until the subcutaneous layer appears. The last ribs are cut into the arch of the sternum to open the chest cavity. Cutting is carried out on the left and right sides. Blood samples are taken from the apex of the heart rate of at least $3 \mathrm{ml}$ using a syringe. Blood is collected into EDTA tubes. Low-speed centrifugation (1000 rpm) at $2-8^{\circ} \mathrm{C}$ for 15 min was performed to extract blood plasma.

\section{Histopathological investigation}

After tissue samples were cleaned with saline, they were immediately fixed in $10 \%$ formaldehyde solution at room temperature for $72 \mathrm{~h}$ and prepared for routine light microscope examination. The tissue samples were dehydrated with alcohol and cleaned with xylene before being immersed in paraffin. Fivemicrometer slices of the tissues were made. The tissues were stained with hematoxyline-eosin ( $\mathrm{H}$ and $\mathrm{E}$ ), and the section was examined and photographed with a light microscope.

\section{ADMA}

ADMA levels in plasma were measured by using a kit from Elabsience (Cat. No: E-EL-0042). The result was determined by the Enzyme-linked Immunosorbent Assay method and reported as nanogram per milliliter $(\mathrm{ng} / \mathrm{mL})$

\section{Statistical analysis}

Data were analyzed statistically based on variables assessed using a computerized system that is univariate and bivariate analysis. Univariate analysis was performed to see the frequency distribution of variables. Bivariate analysis is performed to analyze the relationship between the independent variables and the dependent variable. The relationship between the three variables was analyzed using one-way ANOVA. Statistical significance was accepted as $p<0.05$.

\section{Results}

Isoproterenol injection, dose $85 \mathrm{mg} / \mathrm{kg} \mathrm{BW}$ subcutaneously for 2 consecutive days, causes acute myocardial infarction in the positive control and treatment groups. This study found that the injection of isoproterenol dose $85 \mathrm{mg} / \mathrm{kg} \mathrm{BW}$ caused the spread of edema in most of the myocardium, characterized by swollen interstitial areas, dilated capillaries, and inflammatory cells consisting of lymphocytes, neutrophils, and histiocytes. In some muscle cells, visible signs of degeneration are characterized by granular and paler changes in the cytoplasm (Figure 1).

\section{Discussion}

Two mechanisms cause myocardial infarction induced by isoproterenol, and the first biochemical mechanism occurs due to the formation of free radicals and lipid peroxide accumulation [9], [10]. Second, molecular mechanisms occur due to decreased eNOS activity, causing a decrease in NO levels. These mechanisms are caused by oxidative stress-mediated by increased ROS or reduced antioxidants in the defense system [11]. NO is a reactive gas diffusible 
produced by arginine oxidation from 3 isoforms of NO Synthase, which are neuronal, inducible, and eNOS (nNOS, iNOS, eNOS). Isoproterenol-induced myocardial infarction significantly reduces eNOS protein expression and decreases NO [12].

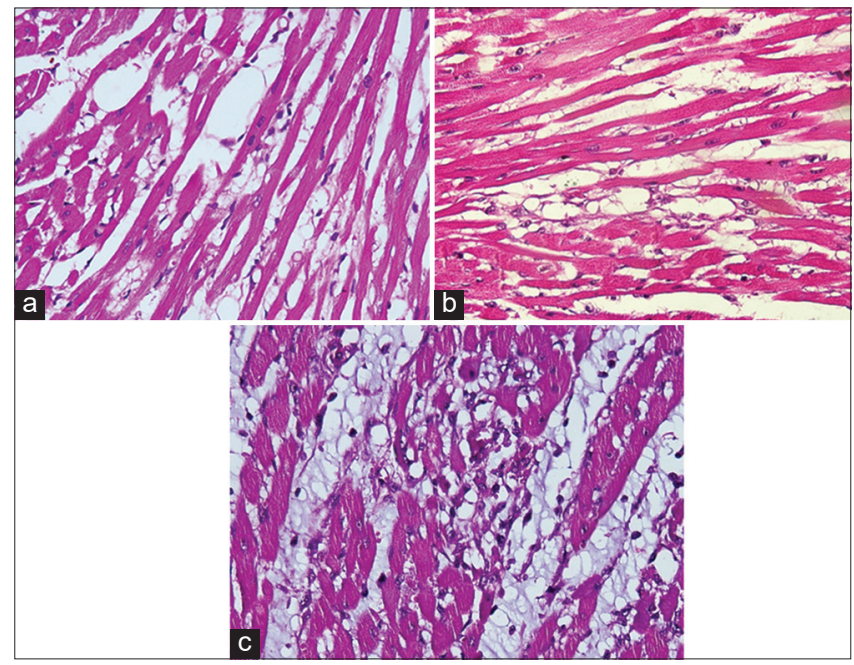

Figure 1: (a) Hematoxylin and eosin ( $H$ and $E)$ stained of heart tissue on negative control group; (b) ( $H$ and $E)$ stained of heart tissue after induction by isoproterenol; (c) $H$ and $E$ stained of heart tissue on pretreatment with Ramipril $3 \mathrm{mg} / \mathrm{kg} \mathrm{BW}$

Based on Table 1, the negative control group had an average plasma ADMA level is $133.08 \mathrm{ng} / \mathrm{mL}$ and was the lowest average ADMA level compared to the other groups. Table 1 also shows significantly higher plasma ADMA levels in the positive control group after the isoproterenol $85 \mathrm{mg} / \mathrm{kg}$ BB with a mean value of $210.15 \mathrm{ng} / \mathrm{mL}$ than the mean of plasma ADMA levels negative control.

Table 1: ADMA Values measured in blood samples of the groups (ng/mL)

\begin{tabular}{ll}
\hline Group & Mean of ADMA Level \pm SD \\
\hline Negative control group & $133.08 \pm 14.97$ \\
Positive control group & $188.44 \pm 19.28$ \\
Treatment group & $240.94 \pm 39.62$ \\
p-value & 0.0001 \\
\hline ADMA: Asymmetric dimethylarginine. &
\end{tabular}

Differences in mean plasma ADMA levels in positive and negative controls indicate an increase in ADMA levels in acute myocardial infarction. These results are consistent with statements in a study conducted by Li et al. in 2012, which stated a significant increase in plasmaADMAlevels of mice that experienced acute myocardial infarction after isoproterenol-induced dose $85 \mathrm{mg} / \mathrm{kg}$ BW [13]. Myocardial infarction caused by oxidative stress caused by isoproterenol. Oxidative stress will cause disruption of DDAH enzyme activity, resulting in gradual vasoconstriction and result in the accumulation of plasma levels of ADMA.

ADMA is an endogenous inhibitor of eNOS that competitively inhibits NO production and plays an essential role as a predictor of cardiovascular disease [13]. ADMA is derived from arginine residues in methylated proteins by the enzyme Arginine Methyltransferase Type 1 (PRMT1), an isoform dominant arginine protein methyltransferase in mammalian cells. Circulating ADMA is degraded by the body with the help of the enzymes DDAH1 and DDAH2. DDAH1 is usually found in tissues that express nNOS, whereas DDAH2 predominates in tissues that express eNOS. DDAH2 metabolizes more than $90 \%$ of ADMA, and only a little is excreted in the urine [13], [14].

The mechanism responsible for endothelial dysfunction in isoproterenol-induced myocardial infarction is a buildup of ADMA. This increase in ADMA levels is related to oxidative stress-mediated by increased ROS or reduction in antioxidants. Free radicals formed to cause the decrease in the enzyme DDAH2, which is the main enzyme to metabolize ADMA. The inhibition of eNOS by ADMA becomes the primary pathogenic mechanism involved in cardiovascular disease [13], [14]. Particularly, the inhibition of eNOS results in decreased NO levels, which is a crucial signaling molecule in endothelial cells involving cardiovascular diseases. The NO levels released by eNOS in endothelial cells are essential for the maintenance of basal vascular tone [15], [16], [17].

Based on Table 1, the average plasma ADMA level after administration of Ramipril with a dose of $3 \mathrm{mg} / \mathrm{kg} \mathrm{BW}$ in the treatment group was $240.94 \mathrm{ng} / \mathrm{mL}$. Based on one-way ANOVA statistical test p-value $<0.05$, which means there is a significant influence between the administration of Ramipril dose of $3 \mathrm{mg} / \mathrm{kg}$ BW on plasma ADMA levels. Post hoc test showed that the ADMA levels between all groups were significantly different (negative vs. positive control, $p=0.007$; negative vs. treatment group, $p<0.001$; and positive vs. treatment, $p=0.011$ ).

The cardioprotective effect of ACE-I on cardiovascular disorders is mainly caused by inhibition of bradykinin degradation in addition to inhibition of ACE. Bradykinin facilitates the formation of $\mathrm{NO}$ and prostaglandins, both of which are also useful in treating myocardial infarction. This concept might not apply to the acute phase of myocardial infarction caused by excessive adrenergic stimulation [18]. This statement is proven by research conducted by Ohta et al. in improving ventricular function compared to the group given only ACE-I.

In contrast to previous studies that stated that the administration of ACE-I could reduce ADMA levels [8], [19], in this study based on Table 1 shows ADMA levels in the treatment group experienced a significantly higher than the control group. This finding is in line with research conducted by Gamboa et al., which also received an increase in ADMA levels after pretreatment with Ramipril for 7 consecutive days [20].

The average increase in ADMA levels in the treatment group is caused by ACE-I given to experimental animals can increase bradykinin levels [20]. ACE-Inhibitors inhibit the degradation of bradykinin so that bradykinin formed locally in the vascular will 
increase [7], [21]. The increase in ADMA levels through bradykinin is proven by research in vitro conducted by Gamboa et al., who found that ADMA levels increased after the cellular model of alveolar adenocarcinoma in humans (A459) was incubated with bradykinin. In contrast, incubation with bradykinin B1 receptor inhibitors did not reduce ADMA levels. This shows that elevated levels of ADMA induced by bradykinin occur through the B2 bradykinin receptor [20].

A previous study by Larsen et al. demonstrated that bradykinin triggers ROS production via NADPH oxidase [22]. Furthermore, the NADPH oxidase increases PRMT, an enzyme involving in ADMA production, as well as inhibits ADMA degradation, resulting in the increase of ADMA [23], [24]. Another explanation that can increase ADMA levels is that bradykinin can reduce the activity of DDAH, which is responsible for ADMA degradation [25]. Thus, Ramipril may increase ADMA levels by increasing bradykinin and oxidative stress.

\section{Conclusions}

This study concluded that pretreatment with Ramipril increased ADMA concentration in acute myocardial infarction rats induced by isoproterenol.

\section{Acknowledgments}

We thank all administration staff in Universitas Andalas for their support in this research.

\section{References}

1. Li H, Xie YH, Yang Q, Wang SW, Zhang BL, Wang JB, et al Cardioprotective effect of paeonol and danshensu combination on isoproterenol-induced myocardial injury in rats. PLoS One. 2012;7(11):e48872. https://doi.org/10.1371/journal. pone. 0048872

PMid:23139821

2. Higashi $\mathrm{Y}$, Maruhashi T, Noma K, Kihara Y. Oxidative stress and endothelial dysfunction: Clinical evidence and therapeutic implications. Trends Cardiovasc Med. 2014;24(4):165-9. https:// doi.org/10.1016/j.tcm.2013.12.001

PMid:24373981

3. Su JB. Vascular endothelial dysfunction and pharmacological treatment. World J Cardiol. 2015;7(11):719-41. https://doi. org/10.1016/s0008-6363(02)00617-x

PMid:26635921

4. Sydow K, Schwedhelm E, Arakawa N, Bode-Böger SM, Tsikas D,
Hornig $\mathrm{B}$, et al. ADMA and oxidative stress are responsible for endothelial dysfunction in hyperhomocyst(e)inemia: Effects of L-arginine and B Vitamins. Cardiovasc Res. 2003;57(1):244-52. PMid: 12504835

5. Steyers $\mathrm{CM} 3^{\text {rd }}$, Miller FJ Jr. Endothelial dysfunction in chronic inflammatory diseases. Int J Mol Sci. 2014;15(7):11324-49. https://doi.org/10.3390/ijms150711324

PMid:24968272

6. Her AY, Choi BG, Rha SW, Kim YH, Choi CU, Jeong MH. The impact of angiotensin-converting-enzyme inhibitors versus angiotensin receptor blockers on 3-year clinical outcomes in patients with acute myocardial infarction without hypertension. PLoS One. 2020;15(11):e0242314. https://doi.org/10.1371/ journal.pone. 0242314

PMid:33253206

7. Erdös EG, Tan F, Skidgel RA. Angiotensin I-converting enzyme inhibitors are allosteric enhancers of kinin B1 and B2 receptor function. Hypertension. 2010;55(2):214-20. https://doi. org/10.1161/hypertensionaha.109.144600

PMid:20065150

8. Chen JW, Hsu NW, Wu TC, Lin SJ, Chang MS. Long-term angiotensin-converting enzyme inhibition reduces plasma asymmetric dimethylarginine and improves endothelial nitric oxide bioavailability and coronary microvascular function in patients with syndrome X. Am J Cardiol. 2002;90(9):974-82. https://doi.org/10.1016/s0002-9149(02)02664-4

PMid:12398965

9. Allawadhi P, Khurana A, Sayed N, Kumari P, Godugu C Isoproterenol-induced cardiac ischemia and fibrosis: Plant-based approaches for intervention. Phytother Res. 2018;32(10):1908-32. https://doi.org/10.1002/ptr.6152 PMid:30009418

10. Iqbal $R$, Akhtar $M S$, Hassan $M Q$, Jairajpuri Z, Akhtar $M$, Najmi AK. Pitavastatin ameliorates myocardial damage by preventing inflammation and collagen deposition via reduced free radical generation in isoproterenol-induced cardiomyopathy. Clin Exp Hypertens. 2019;41(5):434-43. https://doi.org/10.1080 /10641963.2018.1501059

PMid:30192645

11. Sampath PD, Kannan V. Mitigation of mitochondrial dysfunction and regulation of eNOS expression during experimental myocardial necrosis by alpha-mangostin, a xanthonic derivative from Garcinia mangostana. Drug Chem Toxicol. 2009;32(4):34452. https://doi.org/10.1080/01480540903159210 PMid: 19793027

12. Yu X, Ge L, Niu L, Lian X, Ma H, Pang L. The dual role of inducible nitric oxide synthase in myocardial ischemia/reperfusion injury: Friend or foe? Oxid Med Cell Longev. 2018;2018:8364848. https://doi.org/10.1155/2018/8364848 PMid:30510628

13. Li X, Wang X, Guo Y, Deng N, Zheng P, Xu Q, et al. Regulation of endothelial nitric oxide synthase and asymmetric dimethylarginine by matrine attenuates isoproterenol-induced acute myocardial injury in rats. J Pharm Pharmacol. 2012;64(8):1107-18. https:// doi.org/10.1111/j.2042-7158.2012.01502.x

PMid:22775214

14. Zhou R, Ma P, Xiong A, Xu Y, Wang Y, Xu Q. Protective effects of low-dose rosuvastatin on isoproterenol-induced chronic heart failure in rats by regulation of DDAH-ADMA-NO pathway. Cardiovasc Ther. 2017;35(2):e12241. https://doi. org/10.1111/1755-5922.12241

PMid:27957828

15. Marra M, Marchegiani F, Ceriello A, Sirolla C, Boemi M, Franceschi $\mathrm{C}$, et al. Chronic renal impairment and DDAH2$1151 \mathrm{~A} / \mathrm{C}$ polymorphism determine ADMA levels in Type 2 
diabetic subjects. Nephrol Dial Transplant. 2013;28(4):964-71 https://doi.org/10.1093/ndt/gfs516

PMid:23129820

16. Dayem SM, Battah AA, Bohy AE, Ahmed S, Hamed M Fattah SN. Nitric oxide gene polymorphism is a risk factor for diabetic nephropathy and atherosclerosis in Type 1 diabetic patients. Open Access Maced J Med Sci. 2019;7(19):3132-8. https://doi.org/10.3889/oamjms.2019.831

PMid:31949504

17. Elfi EF, Decroli E, Nasrul E, Yanwirasti Y, Darwin E. The risk factors of coronary heart disease and its relationship with endothelial nitric oxide synthase. Open Access Maced J Med Sci. 2021;9(B):451-6. https://doi.org/10.3889/oamjms.2021.6062

18. Ohta T, Hasebe N, Tsuji S, Izawa K, Jin YT, Kido S, et al. Unequal effects of renin-angiotensin system inhibitors in acute cardiac dysfunction induced by isoproterenol. Am J Physiol Heart Circ Physiol. 2004;287(6):H2914-21. https://doi.org/10.1152/ ajpheart.00221.2004

PMid:15297251

19. Delles C, Schneider MP, John S, Gekle M, Schmieder RE. Angiotensin converting enzyme inhibition and angiotensin II AT1-receptor blockade reduce the levels of asymmetrical $N(G), N(G)$-dimethylarginine in human essential hypertension. Am J Hypertens. 2002;15(7):590-3. https://doi.org/10.1016/ s0895-7061(02)02278-1

PMid: 12118904

20. Gamboa JL, Pretorius M, Sprinkel KC, Brown NJ, Ikizler TA. Angiotensin converting enzyme inhibition increases ADMA concentration in patients on maintenance hemodialysis-a randomized cross-over study. BMC Nephrol. 2015;16:167. https://doi.org/10.1186/s12882-015-0162-x PMid:26494370

21. Ancion A, Tridetti J, Trung ML, Oury C, Lancellotti P. A review of the role of bradykinin and nitric oxide in the cardioprotective action of angiotensin-converting enzyme inhibitors: Focus on perindopril. Cardiol Ther. 2019;8(2):179-91. https://doi. org/10.1007/s40119-019-00150-w

\section{PMid:31578675}

22. Larsen BT, Bubolz AH, Mendoza SA, Pritchard KA Jr. Gutterman DD. Bradykinin-induced dilation of human coronary arterioles requires NADPH oxidase-derived reactive oxygen species. Arterioscler Thromb Vasc Biol. 2009;29(5):739-45. https://doi.org/10.1161/atvbaha.108.169367

\section{PMid:19213944}

23. Luo Z, Teerlink T, Griendling K, Aslam S, Welch WJ, Wilcox CS Angiotensin II and NADPH oxidase increase ADMA in vascular smooth muscle cells. Hypertension. 2010;56(3):498-504. https://doi.org/10.1161/hypertensionaha.110.152959 PMid:20696982

24. Wilcox CS. Asymmetric dimethylarginine and reactive oxygen species: Unwelcome twin visitors to the cardiovascular and kidney disease tables. Hypertension. 2012;59(2):375-81. https://doi.org/10.1161/hypertensionaha.111.187310

PMid:22215715

25. Firinu D, Bassareo PP, Zedda AM, Barca MP, Crisafulli A, Mercuro G, Del Giacco S. Impaired endothelial function in hereditary angioedema during the symptom-free period. Front Physiol. 2018;9:523. https://doi.org/10.3389/fphys.2018.00523 PMid:29867566 